\title{
Development of Array-based Technology for Detection of HAV Using Gold-DNA Probes
}

\author{
Zhixiang Wan, Yefu Wang,*, Shawn Shun-cheng $\mathrm{Li}^{\dagger}{ }^{\dagger}$, , Lianlian Duan and Jianxin Zhai \\ Department of Biotechnology, College of Life Sciences, Wuhan University, Wuhan 430072, P. R. China \\ Department of Biochemistry, University of Western Ontario, London, Ontario N6A 5C1, Canada
}

Received 11 December 2004, Accepted 2 March 2005

\begin{abstract}
A sensitive method for detection of Hepatitis A virus (HAV) by utilizing gold-DNA probe on an array was developed. Amino- modified oligodeoxynucleotides at the $5^{\prime}$ position were arrayed on an activated glass surface to function as capture probes. Sandwich hybridization occurred among capture probes, the HAV amplicon, and gold nanoparticlesupported oligonucleotide probes. After a silver enhancement step, signals were detected by a standard flatbed scanner or just by naked eyes. As little as $100 \mathrm{fM}$ of HAV amplicon could be detected on the array. Therefore, the array technology is an alternative to be applied in detection of HAV due to its low-cost and high-sensitivity.
\end{abstract}

Keywords: Array, Gene detection, Gold-DNA probe, HAV, Sensitivity

\section{Introduction}

Hepatitis A virus (HAV), a major cause of acute hepatitis infections in humans in many countries, is a positive strand RNA virus belonging to the picornavirus family. HAV infection occurs primarily by the fecal-oral route, by personto-person contact or through the ingestion of contaminated food or water. Thus, it is essential to develop special and efficacious methods for the detection of HAV in clinical or biological samples. Sequence-specific gene detection has been a topic of significant interest because of its application in areas ranging from the environmental monitoring to diagnostics. Several laboratories have attempted to develop methods based on the polymerase chain reaction (PCR) or nucleic acid hybridization for detecting the HAV gene (Therasal et al., 1997; David HK et al., 2002). But, these methods need

\footnotetext{
*To whom correspondence should be addressed.

Tel: 86-27-68754627; Fax: 86-27-68754627

E-mail: wangyf86@yahoo.com.cn
}

improvement, especially in regard to the false positive incidence with PCR methods. There remains a need to develop a more sensitive and specific detection method for the HAV gene at low cost. Microarray-based biological techniques play an important role in gene detection. The development of these techniques is driven by the need for low cost, minimal sample consumption, high throughput and efficiency.

In recent years, the application of gold nanoparticles as oligonucleotide labels instead of fluorescence dyes in DNA detection assays was very common. Gold nanoparticles were also used for microgravimetric analysis of DNA in connection with dendritic signal amplification (Patolsky et al., 2000). Electrochemical stripping detection of a hybridization event based on gold-DNA probes has also been reported (Hong et al., 2002; Urban et al., 2003). Specifically, Mirkin and coworkers exploited a series of DNA detection methods in which gold-DNA probes were utilized (Elghanian et al., 1997; Taton et al., 2000; Taton et al., 2001; Park et al., 2002). Their experiments revealed that gold- labelled probes were compatible with gene microarray or gene-chip and would be used as an alternative marker because of their high stability, high labelling density and superior sensitivity.

To improve the detection signal of gold nanoparticles on the array, a silver enhancement step was included (Alexandre et al., 2001; Csaki et al., 2003). The amplification of signal increased the sensitivity of gene detection and could be detected by flatbed scanner or the naked eyes (Taton et al., 2000). With gold nanoparticle probes amplification coupled with silver enhancement, the sensitivity of microarrays increased markedly. Compared to Cy3-based fluorescence, silver amplified gold nanoparticle probes produce approximately 1000-fold increase in sensitivity (James et al., 2004).

Mirkin and co-workers were first to propose gold nanoparticle modified DNA probe coupled with silver enhancement for DNA microarray probing. Analysis of the microarray with a simple flatbed scanner provided sufficient sensitivity to detect a 50fM concentration of a 30-mer single-stranded DNA target (Taton et al., 2000). We previously reported simultaneous 
diagnosis of $\mathrm{HBV}$ and $\mathrm{HCV}$ using gold nanoparticle probes and silver enhancement method (Wang et al., 2003). Based on this work and with a few improvements, we established a HAV detection technology using gold-DNA probe on an array. Characterization and optimization of the sensitivity of this method were carried out. The $100 \mathrm{fM}$ HAV amplicon was readily detectable after exposing to the silver enhancer solution for 8-12 min.

\section{Materials and Methods}

Reagents Silanizing coupling reagent $-\gamma$-aminopropyltriethoxysilane (APTES) from Organosilicon Engineering Research Center of MOE (Wuhan, China), 1,4-phenylene diisothiocyanate (PDITC, Aldrich), MMLV reverse transcriptase (Biostar Com., Taipei Hsien, Taiwan), Taq DNA polymerase, uracil-DNA glycosylase (UDG, Gene Co. Ltd.), salmon sperm DNA, bovine serum albumin and dNTPs (Promega, Madison, USA) were used as received from the manufactures. Other chemicals and biological reagents were of analytical reagent (AR) grade. All solutions were treated with $0.1 \%$ diethyl pyrocarbonate (DEPC, Sigma, St. Louis, USA). The glassware was pre-cleaned by immersing in aqua regia $\left(\mathrm{HCl}: \mathrm{HNO}_{3}=3: 1\right)$ followed by rinsing with deionized water and then dried at $180^{\circ} \mathrm{C}$ for $8 \mathrm{~h}$. All EP tubes and tips were sterilized under high pressure.

Silver enhancement solution was prepared as follows. Sixty milliliters of $1 \%(\mathrm{w} / \mathrm{v})$ gelatin solution, $10 \mathrm{ml}$ of citric acid buffer (pH 3.8) and $1.7 \mathrm{~g}$ of hydroquinone were dissolved in $30 \mathrm{ml}$, water, filtered and mixed prior to use. Lastly, $50 \mathrm{mg}$ of $\mathrm{AgNO}_{3}$ dissolved in $2 \mathrm{ml}$ water was added to the mixed solution. The freshlyprepared solution was kept away from light. Citric acid buffer $(\mathrm{pH}$ 3.8) was obtained by dissolving $2.55 \mathrm{~g}$ citric acid $\left(\mathrm{C}_{6} \mathrm{H}_{8} \mathrm{O}_{7} \cdot \mathrm{H}_{2} \mathrm{O}\right)$ and $2.35 \mathrm{~g}$ sodium citrate $\left(\mathrm{C}_{6} \mathrm{H}_{5} \mathrm{Na}_{3} \mathrm{O}_{7} \cdot \mathrm{H}_{2} \mathrm{O}\right)$ in $100 \mathrm{ml}$ distilled water. $0.2 \%(\mathrm{w} / \mathrm{v})$ PDITC solution was prepared by mixing anhydrous pyridine and $N, N$-dimethylformamide (DMF) in a ratio of $1: 9$, followed by addition of appropriate amount of PDITC to the mixture.

HAV samples Hepatitis serum samples and sewage samples were received from the Bureau of Import and Export Inspection and Quarantine of Hubei Province, Xiehe Hospital of Huazhong University of Science \& Technology (HUST), Hubei Provincial Yunmeng Blood Station, and Wuhan University Zhongnan Hospital. Samples were stored at $-80^{\circ} \mathrm{C}$ until use.

Sewage samples collected from the contaminated sewage network were ultracentrifuged at $229,000 \mathrm{~g}$ for $1 \mathrm{~h}$ at $4^{\circ} \mathrm{C}$ to sediment the virus particles together with any suspended material. Viruses retained in the sediment were eluted by mixing with $0.25 \mathrm{M}$ glycine buffer ( $\mathrm{pH} 9.5$ ) on ice for $30 \mathrm{~min}$. The suspended solids were then removed by centrifugation at $12,000 \mathrm{~g}$ for $15 \mathrm{~min}$ after the addition of sodium phosphate buffer (PBS). Viruses in the supernatant were pelleted by ultracentrifugation for $1 \mathrm{~h}$ at $4^{\circ} \mathrm{C}$, resuspended in PBS.

Primers and probes Primers and probes were designed with the Primer Premier 5.00 program and synthesized by Shenggong Bioengineering Co. (Shanghai, China). Designed PCR primers and hybridization probes met the following demands: (1) primers and probes of HAV derived from the VP1 region which are highly conservative sequence elements (2323-2571) of HAV gene, (2) capture probes were modified with amino group at 5'-position in order that the probes can covalently attach to the activated glass. 3'mercapto detection probes can associate with gold nanoparticles due to high affinity of mercapto group to gold surface, (3) ten T base inserted into probes increased the distance between the substrate and probes, which reduced the effect of steric hindrance on hybridization of the probes with complementary target DNA(Wang et al., 2003). The primers for amplification of the HAV gene were named A1 and A2. Sequences of primers and probes used are listed in Table 1.

Extraction and amplification of HAV gene RNA extraction by proteinase K Method: One hundred microliters of serum or sewage suspension were treated with an equal volume of proteinase $\mathrm{K}(2 \mathrm{~g} /$

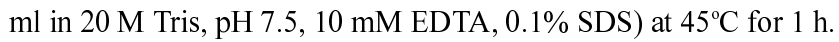
RNA was extracted with phenol-chloroform, precipitated with ethanol, and resuspended in $20 \mathrm{ml}$ DEPC-treated water prior to reverse transcription. After centrifugation, the pellet was washed with $70 \%$ ethanol, air dried, and resuspended in $10 \mu \mathrm{LEPC}$ treated water. Reverse transcription reaction was carried out using $10 \mu \mathrm{l}$ RNA, 25 pmol of the primer A2 and $200 \mathrm{U}$ of reverse transcriptase in a final volume of $20 \mu \mathrm{l}$ at $42^{\circ} \mathrm{C}$ for $1 \mathrm{~h}$, followed by incubation at $95^{\circ} \mathrm{C}$ for $5 \mathrm{~min}$. Twenty microlitres of cDNA was used for PCR.

PCR amplification was carried out in a $100 \mu$ l reaction mixture containing $10 \mathrm{mM}$ Tris- $\mathrm{HCl}\left(\mathrm{pH} 8.3\right.$ at $\left.25^{\circ} \mathrm{C}\right), 50 \mathrm{mM} \mathrm{KCl}, 1.5 \mathrm{mM}$ $\mathrm{MgCl}_{2}, 200 \mu \mathrm{M}$ dNTPs (note that: $2 / 5$ of dTTP was replaced with dUTP), 25 pmol A1 primer and 2 units of Taq DNA polymerase. After denaturation for $4 \mathrm{~min}$ at $94^{\circ} \mathrm{C}$, the DNA was amplified for 30 cycles at $94^{\circ} \mathrm{C}$ for $30 \mathrm{~s}, 40^{\circ} \mathrm{C}$ for $30 \mathrm{~s}$, and $72^{\circ} \mathrm{C}$ for $45 \mathrm{~s}$ (and an additional $5 \mathrm{~min}$ at $72^{\circ} \mathrm{C}$ in the last cycle). The HAV amplicon fragment size was determined by electrophoresis on a $1.5 \%$ agarose gel containing $0.5 \mathrm{mg} / \mathrm{ml} \mathrm{EB}$.

Table 1. Sequences of the synthetic primers and probes

Primer A1 of HAV

Primer A2 of HAV

Capture probe of HAV

Detection probe of HAV

Capture probe of positive control

Detection probe of positive control

Capture probe of negative control

Detection probes of negative control
5'-GATGGATGTTTCAGGAGTG-3' (2323-2341)

5'-TGAGGAGGATTAGAAGTCG-3' (2553-2571)

$5 '-\mathrm{H}_{2} \mathrm{~N}-\left(\mathrm{CH}_{2}\right)_{6}-\mathrm{O}-\left(\mathrm{PO}_{3}\right)-(\mathrm{T})_{10}$-GAGCTATCAGCAACAATTGAAC-3' (2356-2377)

5'-TAAAGAGTACACATTTCCAATA-(T) ${ }_{10}$-SH-3' (2521-2542)

$5 '-\mathrm{H}_{2} \mathrm{~N}-\left(\mathrm{CH}_{2}\right)_{6}-\mathrm{O}-\left(\mathrm{PO}_{3}\right)-(\mathrm{T})_{10}-\mathrm{CTCCCTGAACCGTTCCGCATTCG}-33^{\prime}$ (557-579)

5'-CGTTCTCTAACTATTTCTTTGATA-(T) ${ }_{10}$-SH-3' (927-950)

$5^{\prime}-\mathrm{H}_{2} \mathrm{~N}-\left(\mathrm{CH}_{2}\right)_{6}$-O- $\left(\mathrm{PO}_{3}\right)-(\mathrm{T})_{10}$-AAACTTCTTTAAGTTTTGCG-3'

5'-GCTCAGTTTACTAGTGCCATTTG-(T) ${ }_{10}$-SH-3' 
Preparation of gene array for the detection of HAV Procedures for pretreatment and functionalization of glass slide surfaces and immobilization of DNA probes were similar to the study (Christy et al., 1996). Glass slides (Fan chuan, China) used for gene arrays were washed in hot concentrated $\mathrm{HNO}_{3}$ for $10 \mathrm{~min}$, rinsed with distilled water ( 5 times, 2 min each time), and then dried in an oven at $37^{\circ} \mathrm{C}$. The pre-cleaned slides were soaked for $2 \mathrm{~h}$ in APTES solution prepared by mixing double-distilled water, acetone and APTES in a volume ratio of $15: 280: 6$, washed 5 times with acetone ( $5 \mathrm{~min}$ each time), and then dried. The slides were subsequently kept in $0.2 \%$ PDITC solution at $37^{\circ} \mathrm{C}$ for $2 \mathrm{~h}$ and then washed 3 times with methanol ( 5 min each time), 2 times each with acetone and double-distilled water, and air dried.

The 5' amino-modified DNAs (HAV, positive and negative controls) for surface-immobilization were diluted in a $1 \mathrm{M} \mathrm{NaCl}, 10$ $\mathrm{mM}$ sodium phosphate buffer to yield $3.37 \times 10^{-7} \mathrm{M}$ and $3.37 \times 10^{-8}$ $\mathrm{M}$ working solution. One microlitre droplets of solution were applied to every designated binding spot and the arrays were incubated in a humidity chamber at $37^{\circ} \mathrm{C}$ for $2 \mathrm{~h}$. Afterwards, the arrays were washed with distilled water $(1 \times 2 \mathrm{~min})$, blocked with $1 \%$ bovine serum albumin (BSA) with shaking at $45^{\circ} \mathrm{C}$ for $30 \mathrm{~min}$, rinsed with distilled water $(3 \times 3 \mathrm{~min})$ and dried at $40-45^{\circ} \mathrm{C}$. The gene arrays obtained were stored at $4-8^{\circ} \mathrm{C}$.

Preparation and size determination of gold nanoparticles Gold nanoparticles were prepared according to the literature (Grabar et al., 1995) by citrate reduction of $\mathrm{HAuCl}_{4}$. The experimental conditions were as follows: $100 \mathrm{ml} \mathrm{HAuCl}_{4}$ solution was brought to boil with stirring at $300 \mathrm{rpm}$. To the solution, $10 \mathrm{~mL} 38.8 \mathrm{mmol} / \mathrm{L}$ sodium citrate solution was added as quickly as possible. The mixture was kept boiling for $15 \mathrm{~min}$, and left to cool at room temperature. The prepared gold nanoparticles were recovered to the original volume with distilled water and filtered through a $0.45 \mu \mathrm{m}$ nylon filter. The size distribution of the resultant gold nanoparticles was measured by transmission electron microscopy (TEM HITACHI H-8100, Japan) and UV-Visible spectrum (UNICO ${ }^{\mathrm{TM}}$, Beijing, China). An average diameter of $14 \pm 2 \mathrm{~nm}$ was obtained. The gold solution exhibited a sharp plasmon absorption band with maximum absorbance at wavelength $520 \mathrm{~nm}$.

Preparation of thiol-modified DNA-gold probes Gold-DNA probes were synthesized by exposing $50 \mu \mathrm{l}$ 3'-thiol modified oligodeoxynucleotides $(32.5 \mu \mathrm{M})$ to $1 \mathrm{ml}$ gold nanoparticle solution for $16 \mathrm{~h}$ at room temperature. The mixture was adjusted to $\mathrm{pH} 7.0$ using $0.1 \mathrm{M} \mathrm{NaCl}, 10 \mathrm{mM}$ sodium phosphate buffer, kept for $40 \mathrm{~h}$ at room temperature, and then centrifuged at $16,000 \mathrm{rpm}$ for 30 $\mathrm{min}$. The precipitates were washed with and re-dispersed in $1 \mathrm{ml}$ of $0.3 \mathrm{M} \mathrm{NaCl}, 10 \mathrm{mM}$ sodium phosphate buffer, $\mathrm{pH}$ 7.0. Different concentrations of gold-DNA probes were prepared by centrifugation and re-dispersion in appropriate volumes of $0.3 \mathrm{M} \mathrm{NaCl}, 10 \mathrm{mM}$ sodium phosphate buffer. The concentration of gold nanoparticles was determined using absorbance values at $520 \mathrm{~nm}$ in conjunction with the molar absorption coefficient (Demers et al., 2000). The gold-DNA probes were stored at $4^{\circ} \mathrm{C}$.

Sandwich hybridization Each tube of PCR product was diluted 10 fold with hybridization buffer $(0.3 \mathrm{M} \mathrm{NaCl} / 10 \mathrm{mmol} / \mathrm{L} \mathrm{pH} 7.0$ PBS). Meanwhile, $1000 \mathrm{fM} \mathrm{E}$. coli gene was used as positive control. The DNAs were heated in a slightly boiling water bath for $5 \mathrm{~min}$, rapidly cooled in an ice bath for $2 \mathrm{~min}$ and were loaded on to the prepared HAV array chip. Hybridization was carried out in a humidity chamber at $50^{\circ} \mathrm{C}$ for $2 \mathrm{~h}$. The array was washed twice with $0.3 \mathrm{M}$ PBS solution to remove non-hybridized and nonspecific products. Subsequently, the array was treated with a $0.3 \mathrm{M}$ PBS solution of nanoparticle probes. Hybridization was carried out in a moist chamber at $40^{\circ} \mathrm{C}$ for another $2 \mathrm{~h}$. The HAV array was rinsed three times ( 3 min each time) with $0.3 \mathrm{M} \mathrm{NaNO}_{3}$ in $10 \mathrm{mM}$ phosphate buffer $(\mathrm{pH} 7)$ to remove chloride ions.

Silver enhancement and detection The arrays were immersed in a silver enhancer solution, as described above, at room temperature for 8-12 min. When appearance of positive control signal spots was evident, the chip was removed from the silver enhancer solution and rinsed immediately with water, and air-dried. The HAV array signal can be detected by the naked eye or with a flatbed scanner. In this method, arrays were imaged using a standard flatbed scanner (Founder, China) in reflective mode. Image and statistical analysis of the data were performed using software provided by the manufacturer.

\section{Results and Discussion}

The principle of the HAV detection array based on gold-DNA probe coupled with silver enhancement is illustrated in Fig. 1A. The main procedure taken for HAV array detection was as follows. (1) Amino-modified capture probes were covalently immobilized on to PDITC functionalized APTES-glass surface; (2) Sandwich hybridization among capture probes and HAV PCR products and gold-DNA probes; (3) Catalytic precipitation of silver onto the gold nanoparticle followed by flatbed scanner imaging or eye inspection. The pattern of HAV detection arrays was designed as shown in Fig. 1B. Glass substrates $2.5 \times 3 \mathrm{~cm}$ were cut from super-flat slides. Each row was immobilized different capture probe. Row A represents positive control spots, row B represents HAV detection spots, and row $\mathrm{C}$ represents negative control spots. Columns 1, 2, 3, 4 represent the different detection spots of repetition and variability. The concentration of the probes of columns 1 and 2 is $3.37 \times 10^{-7} \mathrm{M}$, the concentration of the probes of columns 3 and 4 is $3.37 \times 10^{-8} \mathrm{M}$. The control system was composed of two parts: (1) negative control was reconstructed gene fragment which was not complementary with HAV, (2) Positive control was the 413 bp fragment of E.coli tnaA gene (547-959), which was not homologous with HAV and synthesized by Shenggong Bioengineering Co. (China).

Characteristics of gold labeled probe In a typical HAV detection array, stability of gold labeled probe is a crucial factor. To characterize the stability of gold probes, TEM was used to determine the size and the morphology of $\mathrm{Au}$ nanoparticles. The prepared DNA-gold nanoparticle solution exhibits substantially high stability (Storhoff et al., 1998). Increased stability of DNA-modified nanoparticles is due to higher oligonucleotide surface coverage, which leads to 


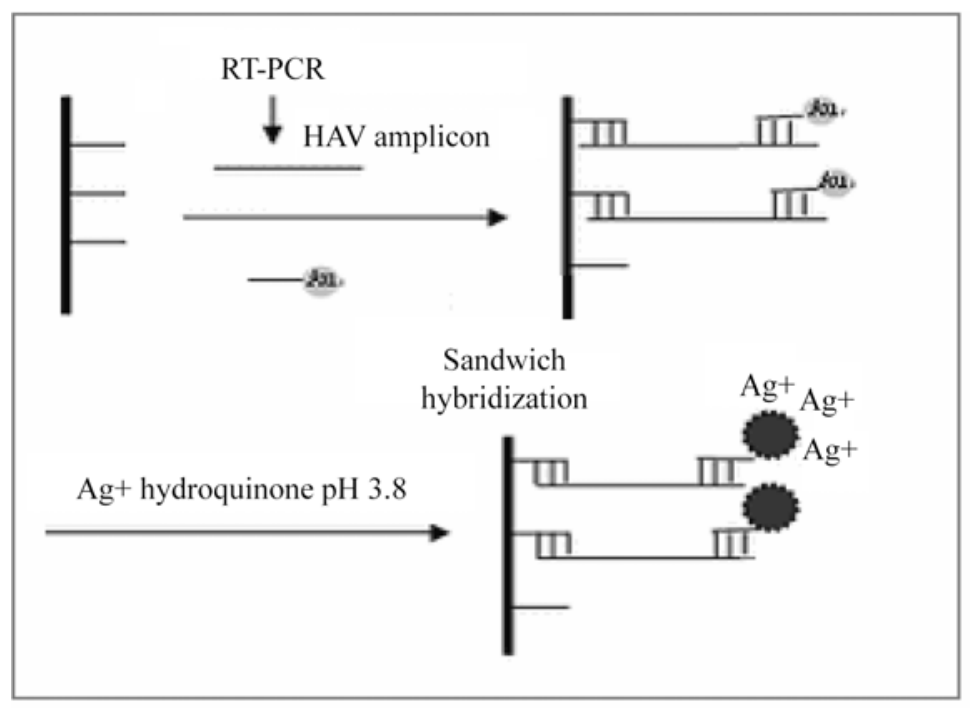

(A)

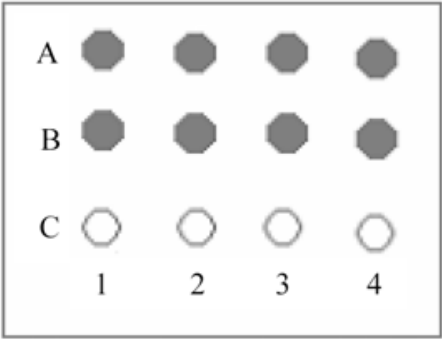

(B)

Fig. 1. The principle (A) and pattern (B) of the HAV array detection. In pattern (b): Positive controls were arranged in row A, detection spots of HAV were arranged in row B, and negative controls were arranged in row C. Columns 1, 2, 3, 4 represent the different detection spots of repetition and variability. The concentration of the probes of columns 1 and 2 is $3.37 \times 10^{-7} \mathrm{M}$, the concentration of the probes of columns 3 and 4 is $3.37 \times 10^{-8} \mathrm{M}$.

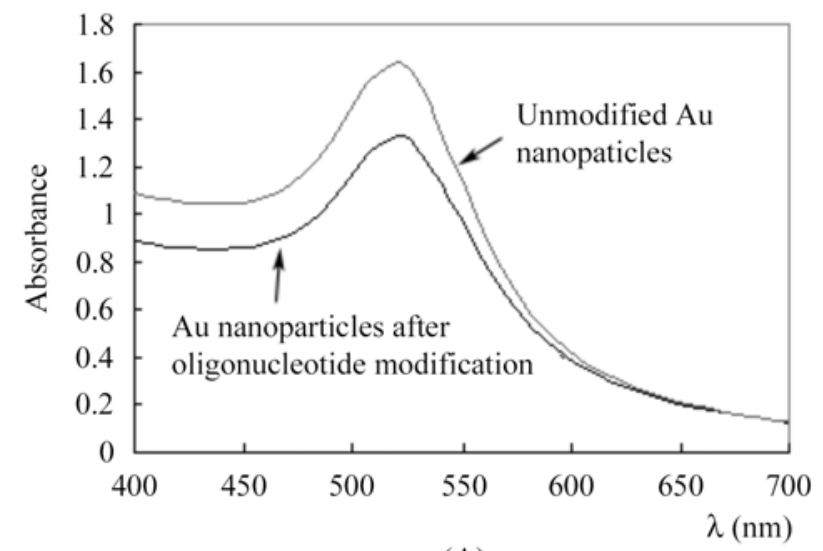

(A)

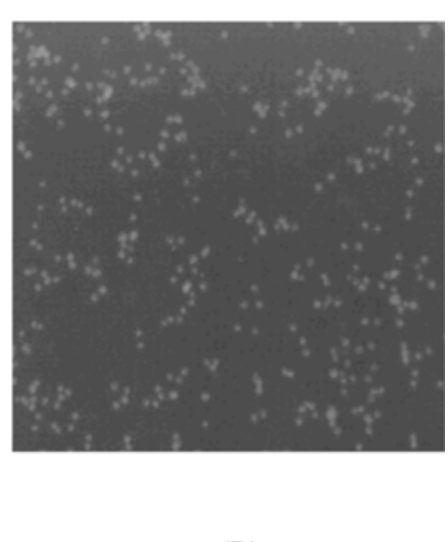

(B)

Fig. 2. Characteristics of the nanoparticles. (A) Comparison between UV-Vis spectum of Au colloids and gold-DNA probes. (B) TEM image DNA-gold nanoparticles (standing for 6 month at $4^{\circ} \mathrm{C}$ ). Briefly, a drop $(50 \mu \mathrm{l})$ of colloidal gold suspension was deposited on a nicked grid and allowed to evaporate at room temperature. The grid was then observed at a magnification of $22,000 \times$.

greater steric and electrostatic protection (Demers et al., 2000). The prepared DNA-gold nanoparticles (left standing for 6 months at $4^{\circ} \mathrm{C}$ ) did not show detectable aggregation by TEM after heating for 2 hour at $60^{\circ} \mathrm{C}$, as demonstrated in Fig. 2B. The prepared DNA-gold nanoparticle conjugates were much more stable than bare Au colloids when exposed to increased salt concentrations and elevated temperatures. In high salt buffers $(0.3 \mathrm{M} \mathrm{NaCl})$, bare Au colloids showed an immediate color change from red to black, which indicated that $\mathrm{Au}$ colloids occurred irreversible aggregation. The UVVis spectra scanned $\mathrm{Au}$ colloids in aqueous solution and DNA-gold nanoparticles at $0.3 \mathrm{M} \mathrm{NaCl} / 10 \mathrm{mM}$ PBS, respectively. After modification, the maximum absorbance had no obvious shift, as shown in Fig. 2a. An obvious decrease in absorbance at $520 \mathrm{~nm}$ of DNA-gold nanoparticle solution was observed, because approximately $25-30 \%$ of the nanoparticles in original solution were lost during centrifugation. The absorbance curve of the stored DNA-gold nanoparticles (left standing for 6 months at $4^{\circ} \mathrm{C}$ ) had no apparent change, and was similar to that of the fresh DNA-gold nanoparticle.

Characterization and purification of HAV amplicon To determine the size and specificity of HAV amplified products before establishing the HAV array detection method, HAV amplicons were analyzed and purified. HAV amplicons were separated by agarose (1.5\%) gel electrophoresis at electric field strength of $6 \mathrm{~V} / \mathrm{cm}$ and detected by ultraviolet light. An expected band was observed (lane B) and determined to be 


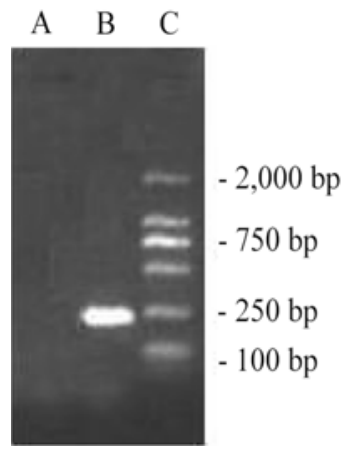

Fig. 3. Agarose gel electrophoresis of HAV amplicon. A: Negative control; B: HAV; C: Marker.

249 bp when compared to the PCR marker (Tube C) as shown in Fig. 3.

HAV PCR product was added in $100 \mu 1$ aliquots to each tube containing $1,500 \mu \mathrm{l}$ of $100 \%$ ice-cold isopropanol and the tubes were centrifuged at $14,000 \mathrm{rpm}$ for $30 \mathrm{~min}$ to pellet the PCR product. The pellet was washed in $75 \%$ ethanol and re-pelleted by centrifugation at 14,000 rpm for $15 \mathrm{~min}$. After centrifugation the pellet was re-suspended in $10 \mu \mathrm{lddH}$.

Optimization of capture probe concentration on HAV detection arrays In order to explore the most suitable concentration of amino-modified DNA probes on the HAV arrays under BSA-blocked conditions, three kinds of capture probes (HAV, positive control, and negative control) were each diluted in 10 fold increments to produce a series of probe concentrations ranging from $3.37 \times 10^{-5} \mathrm{M}$ to $3.37 \times 10^{-10} \mathrm{M}$. Various concentrations of capture probes were attached to the activated glass slide in a predefined pattern (Fig. 4A). The results showed that when the capture probe concentrations were higher than $3.37 \times 10^{-6} \mathrm{M}$, the spot intensities of HAV and positive control were weak and not significantly different from those of the negative control.

The slope of the signal versus concentration plots is another indicator of the dynamic range for capture probe concentration

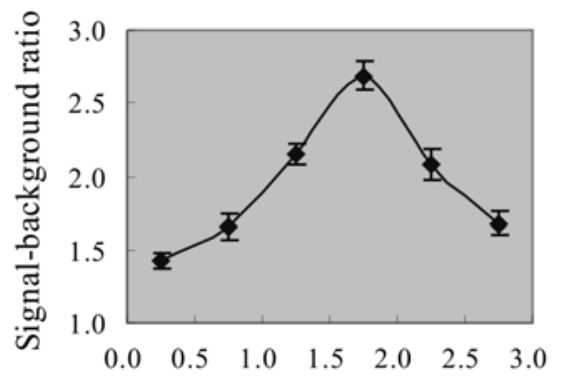

Concentration of gold-DNA probes (nM)

Fig. 5. Influence of concentration of gold nanoparticle probes on signal-to-background ratio. The Y-axis is the ratio of HAV spots intensity to the background intensity. Concentration of positive control or HAV amplicon was $1,000 \mathrm{fM}$. Results are the means of four array replicates.

(Fig. 4B). Signal intensity of positive control could obtain a best result at the concentration of $3.37 \times 10^{-7} \mathrm{M}$. When the concentrations were below $3.37 \times 10^{-8} \mathrm{M}$, the HAV spot intensities showed a weakening signal, which were the same as that of positive controls. Based on these observations, we concluded that the optimal spotting concentrations of aminomodified DNA probes were between $3.37 \times 10^{-7} \mathrm{M}$ and $3.37 \times 10^{-8} \mathrm{M}$. Concentrations above or below this range were less likely to generate optimal results.

Influence of gold nanoparticle probe concentration on signal-to-background ratio After silver enhancement, the gold-labeled DNA chip yielded a high signal-to-background ratio (Reichert et al., 2000). With concentrations of DNAmodified particles increasing, a few gold nanoparticles can be adsorbed to the chip surface due to unspecific binding, resulting in an increased background signal. Unspecific binding of DNA-modified nanoparticles to PDC-activated APTES glass surface has been investigated by scanning force microscopy (Möller et al., 2000). Here, the influence of the concentration of DNA-modified nanoparticles on signal-to-

(A)
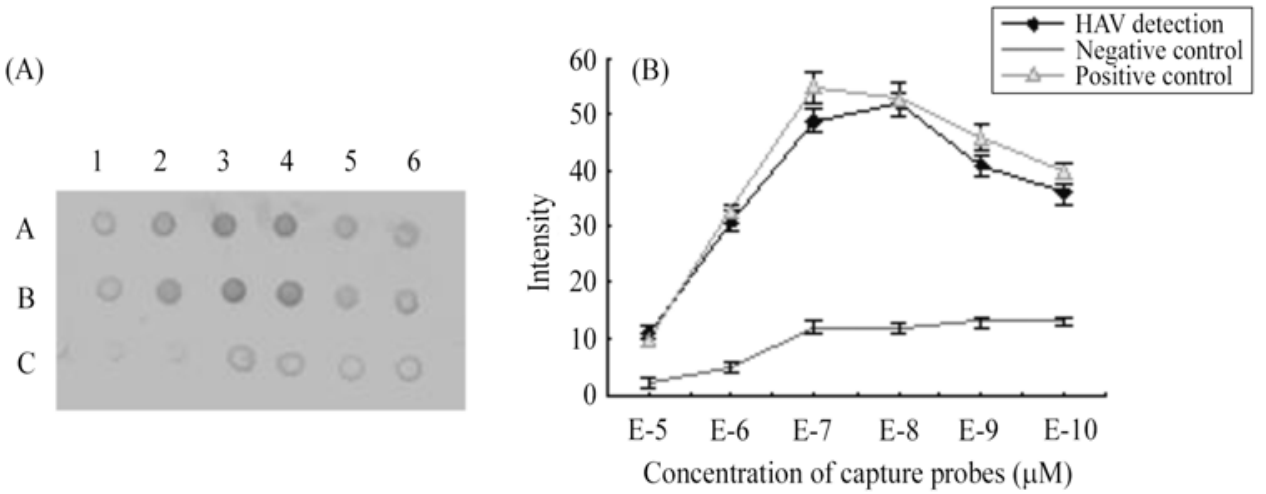

Fig. 4. Different concentrations of capture probes on the HAV detection arrays. A: positive control, B: HAV; C: negative control. The concentration of capture probes: 1 and E-5: $3.37 \times 10^{-5} \mathrm{M}, 2$ and E-6: $3.37 \times 10^{-6} \mathrm{M}, 3$ and E-7: $3.37 \times 10^{-7} \mathrm{M}, 4$ and E-8: $3.37 \times 10^{-8}$ M, 5 and E-9: $3.37 \times 10^{-9} \mathrm{M}, 6$ and E-10: $3.37 \times 10^{-10}$ M. Numbers reported in b represent the means of eight replicates of arrays. Concentration of positive control and HAV amplicon used was 1,000 fM. 

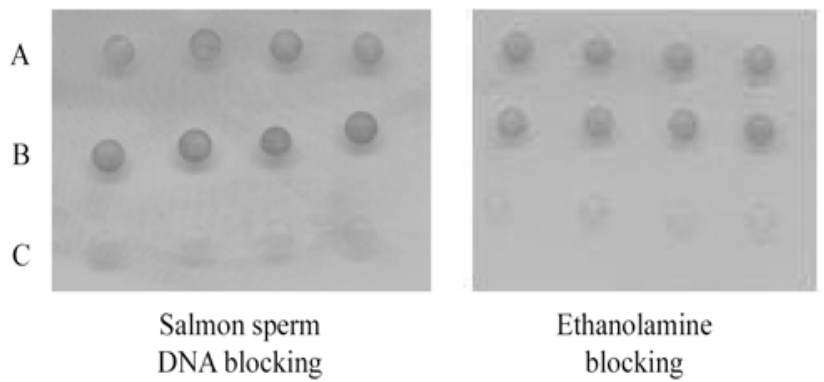

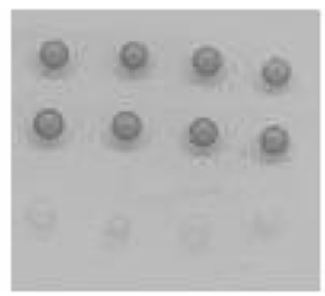

BSA blocking

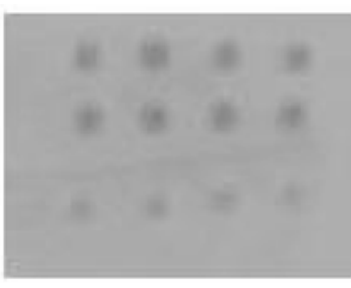

Unblocking

Fig. 6. Detection of HAV employing different blocking strategies on arrays. A: positive control, B: HAV, C: negative control. Concentration of positive control or HAV amplicon was 1,000 fM.

background ratio was investigated, as showed in Fig. 5.

In the present work, the concentration of nanoparticle probe solutions of varied from $0.25 \mathrm{nM}$ to $2.75 \mathrm{nM}$. It was found that the signal intensities were proportional to the concentrations from $0.25 \mathrm{nM}$ to $2.25 \mathrm{nM}$, and the background intensity also increased with the concentrations of gold-DNA probes increasing. When the concentration of HAV gold probes was $1.75 \mathrm{nM}$, a signal-to-background ratio of approximately 2.7 can be determined. However, when the concentrations of probes were higher than $1.75 \mathrm{nM}$, the arrays did not yield a higher signal-to-background ratio, because higher concentration of probes could cause much darker background. On the other hand, when the gold probe concentrations were lower than a certain quantity (e.g., $0.75 \mathrm{nM}$ ), the signal intensities of HAV and positive control were too weak to be clearly discriminated from the negative controls by standard flatbed scanners or the naked eye. Taking the factors into consideration, we estimated that the optimal concentration of nano-gold probes of HAV was $1.75 \mathrm{nM}$. The result of positive control in the test of the DNA-modified nanoparticles concentration was similar to that of HAV (data not shown).

\section{Detection of HAV employing different blocking strategy} on arrays Pre -hybridization blocking strategies are typically used to block the unreacted functional groups of the prepared chip that have low affinity for DNA. Here, blocking reactions are employed to prevent RT-PCR product and labeled probes from non-specific binding to the surface of the array during the hybridization reaction. Three of the common blocking methods to address non-specific adsorption on arrays involve blocking with $1 \%$ salmon sperm DNA, bovine serum albumin (BSA), or ethanolamine.

We explored the following condition for blocking: salmon sperm DNA solution: $1 \times$ Denhardt's solution, $0.1 \%$ SDS, and $100 \mu \mathrm{g}$ of denatured salmon sperm DNA $/ \mathrm{ml}$; BSA solution: $1.0 \% \mathrm{BSA}$ in $3 \mathrm{M} \mathrm{NaCl} / 10 \mathrm{mmol} / \mathrm{L}$ PBS ( $\mathrm{pH} 7.0$ ); ethanolamine solution (Guo et al., 2002): $50 \mathrm{mM}$ ethanolamine, 0.1\% SDS in $\mathrm{H}_{2} \mathrm{O}$, pH 9.0. All glass slides were blocked by one of the three blocking solutions by incubating at $42^{\circ} \mathrm{C}$ for $30 \mathrm{~min}$, followed by washing five times in $\mathrm{ddH}_{2} \mathrm{O}$, then dried. The effect of each of these three blocking strategies to reduce posthybridization background intensity was investigated, and the

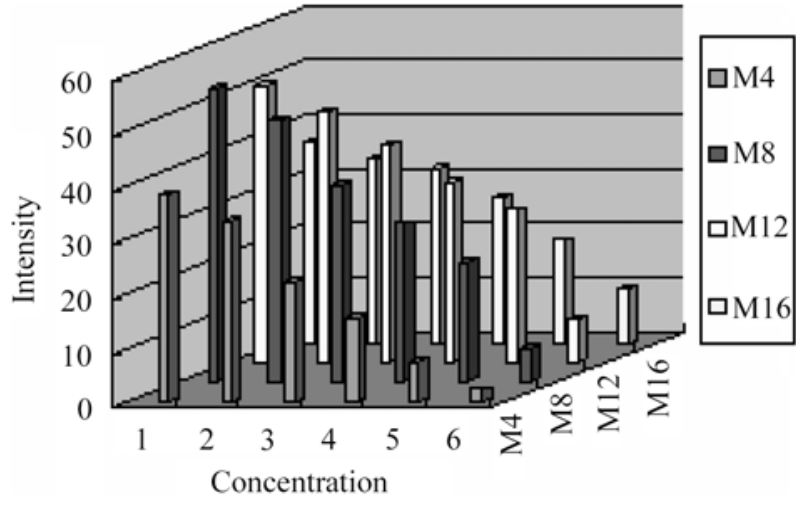

Fig. 7. Intensities of the HAV array were measured at different silver enhancement time and HAV amplicon concentrations. M4, M8, M12, and M16 represent 4, 8, 12, and 16 minutes, respectively. The following concentrations of HAV amplicon were applied: 1; $10,000 \mathrm{fM}, 2: 5,000 \mathrm{fM}, 3: 1,000 \mathrm{fM}, 4: 500 \mathrm{fM}, 5: 100 \mathrm{fM}, 6:$ $50 \mathrm{fM}$. Results are the mean of eight replicates of array.

results are displayed in Fig. 6.

BSA is a globular protein that readily adsorbs to the surface of the prepared array (Hegde et al., 2000). The blocking BSA solution result in lower background intensities compared with the blocking solution containing ethanolamine, or $1 \%$ salmon sperm DNA. Unblocked arrays yielded a lower signal vs. background ratio, and the corresponding signals of detection spots were weak and unclear.

In our previous work (Wang et al., 2003), the blocking strategy of salmon sperm DNA solution was employed, but in this assay the array blocked by BSA displayed the cleaner background than that blocked by salmon sperm DNA solution. And BSA is more economical.

The sensitivity of HAV targets of detection In order to test the sensitivity of HAV detection arrays, different concentrations of HAV targets ranging from 10 to $5000 \mathrm{fM}$ were incubated on separate arrays. After hybridization, silver enhancement was monitored at four different times. The results are shown in Fig. 7. With HAV amplicon concentration increasing, the signal intensified when the time of silver staining was arranged from $4-12 \mathrm{~min}$, but fell at $16 \mathrm{~min}$, due to a marked 
increased in the background intensity. Silver enhancement is based on hydroquinone reduction of silver ions to silver metal at the surface of gold nanoparticles, resulting in a growth of the particles. Silver deposition increases with prolonged exposure to the silver enhancer solution, and the particles exhibit different growth rates, which can be imaged using emission scanning electron microscopy (FE-SEM) (Park et al., 2002).

The results obtained showed that as little as $100 \mathrm{fM}$ of HAV amplicon could be detected on the array after having been exposured to the silver enhancer solution for $12 \mathrm{~min}$. When the concentration of HAV amplicon was $50 \mathrm{fM}$, intensity decreased apparently, and the spots couldn't be detected legibly. With concentrations of HAV amplicon increasing, less time $(8 \mathrm{~min})$ was required for the signal intensity to reach the maximum. Therefore, an exposure time of 8-12 min was optimal.

In conclusion, our results indicated that in this assay, the signal could be significantly strengthened and easily detected without expensive setup. Gold-labeled probe is a promising novel label for microarray and chip technology. Compared with the fluorescence label, it costs less and is more sensitive (Alexandre et al., 2001). A variety of proof-of-principle experiments in the research laboratories point to a powerful technology for molecular diagnostics. In our laboratory, a biochip platform using gold nanoparticles labeling has been built for detection of hepatitis viral genes (Wang et al., 2003; Wang et al., 2004). Due to its high sensitivity and costeffective, the array detection technology can be applied to clinical diagnosis of serum samples, but also to environmental monitoring of HAV contaminated food or water.

Acknowledgments This work was supported by the Hubei Provincial R\&D Program, and Longren Enterprises Group (Wuhan). Many thanks are also acknowledged to Xiehe Hospital, Wuhan seventh Hospital, Hubei Renmin and Zhongnan Hospital and Hubei Import\& Export Disease Inspection Bureau for supplying the HAV samples used in this study.

\section{References}

Alexandre, I., Hamels, S., Dufour, S., Collet, J., Zammatteo, N., De Longueville, F., Gala, J. L. and Remacle, J. (2001) Colorimetric silver detection of DNA microarrays. Anal. Biochem. 295, 1-8.

Chrisey, L. A., Lee, G. U. and O'Ferrall, C. E. (1996) Covalent attachment of synthetic DNA to self-assembled monolayer films. Nucleic Acids Res. 24, 3031-3039.

Csaki, A., Kaplanek, P., Möller, R. and Fritzsche, W. (2003) Single particle sensitivity in the optical detection of individual DNA-conjugated nanoparticle after metal enhancement. Nanotechnology 14, 1262-1268.

David, H. K., Gloria, K. M. and Gary, P. R. (2002) Detection of both hepatitis A virus and norwalk-like virus in imported clams associated with food-borne illness. Appl. Envir. Microbiol. 68, 3914-3918.

Demers, L. M., Mirkin, C. A., Mucic, R. C., Reynolds, R. A., Letsinger, R. L., Elghanian, R. and Viswanadham, G. A. (2000) Fluorescence-based method for determining the surface coverage and hybridization efficiency of thiol-capped oligonucleotides bound to gold thin films and nanoparticles. Anal. Chem. 72, 5535-5541.

Elghanian, R., Storhoff, J. J., Mucic, R. C., Letsinger, R. L. and Mirkin, C. A. (1997) Selective colorimetric detection of polynucleotides based on the distance-dependent optical properties of gold nanoparticles. Science 277, 1078-1081.

Grabar, K. C., Freeman, R. G., Hommer, M. B. and Natan, M. J. (1995) Preparation and characterization of $\mathrm{Au}$ colloid monolayers. Anal. Chem. 67, 735-743.

Guo-Jun, Z., Robert, M., Andrea, C. and Wolfgang, F. (2002) Optical Detection of DNA constructs based on nanoparticles and silver enhancement. AIP Conference Proceedings 640, 1322.

Hegde, P., Qi, R., Abernathy, K., Gay, C., Dharap, S., Gaspard, R., Hughes, J. E., Snesrud, E., Lee, N and Quackenbush, J. (2000) A concise guide to cDNA microarray analysis. Biotechniques 29, 548-550.

Hong, C., Yanqing, W., Pingang, H. and Yuzhi, F. (2002) Electrochemical detection of DNA hybridization based on silver-enhanced gold nanoparticle label. Anal. Chim. Acta. 469, 165-172.

James, J. S., Sudhakar, S. M., Paul, B., Susan, H., H, M., Adam, L., V, G., Tim, P., Wes, B., William, C. and Uwe, R. M. (2004) Gold nanoparticle-based detection of genomic DNA targets on microarrays using a novel optical detection system. Biosens. Bioelectron. 19, 875-883.

Patolsky, F., Ranjit, K. T., Lichtenstein, A. and Willner, I. (2000) Dendritic amplification of DNA analysis by oligonucleotide functionalized Au-nanoparticles. Chem. Commun. 12, 10251026.

Möller, R., Csaki, A., Köhler, J. M. and Fritzsche, W. (2000) DNA probes on chip surfaces studied by scanning force microscopy using specific binding of colloidal gold. Nucleic Acids Res. 28, 20-91.

Park, S. J., Taton, T. A. and Chad, A. M. (2002) Array-based electrical detection of DNA with nanoparticle probes. Science 295, 1503-1506.

Reichert, J., Csaki, A., Möller, R., Köhler, J. M. and Fritzsche, W. (2000) Chip-based optical detection of DNA-hybridization by means of nanobead labelling. Anal. Chem. 72, 6025-6029.

Storhoff, J. J., Elghanian, R., Mucic, R. C., Mirkin, C. A. and Letsinger, R. L. (1998) One-Pot colorimetric differentiation of polynucleotides with single base imperfections using gold nanoparticle probes, J. Am. Chem. Soc. 120, 1959-1964.

Taton, T. A., Mirkin, C. A. and Letsinger, R. L. (2000) Scanometric DNA array detection with nanoparticle probes. Science 289, 1757-1760.

Taton, T. A., Lu, G. and Mirkin, C. A. (2001) Two-color labeling of oligonucleotide arrays via size-selective scattering of nanoparticle probes. J. Am. Chem. Soc. 123, 5164-5165.

Therasal, C., Omanav, H. and M. (1997) Detection of hepatitis A virus RNA in oyster meat. Appl. Envir. Microbiol. 63, 24602463.

Urban, M., Möller, R. and Fritzsche, W. A. (2003) A paralleled 
readout system for an electrical DNA-hybridization assay based on a microstructured electrode array. Rev. Sci. Instrum. 74, 1077-1081.

Wang, Y. F., Pang, D. W., Zhang, Z. L., Zheng, H. Z., Cao, J. P. and Shen, J. T. (2003) Visual gene diagnosis of HBV and
HCV based on nanoparticle probe amplification and silver staining enhancement. J. Med. Virol. 70, 205-211.

Wang, Y. F., Shen, J. T. and Liu, H. H. (2004) Analytical performance of and real sample analysis with an HBV gene visual detection chip. J. Virol. Methods. 121, 79-84. 